\title{
Possible Engraved Canebrake Rattlesnake Motifs on Sherds from the Etoile Site (41NA11) in the Angelina River Basin in East Texas
}

Timothy K. Perttula

Heritage Research Center, Stephen F. Austin State University

Mark Walters

Heritage Research Center, Stephen F. Austin State University

Follow this and additional works at: https://scholarworks.sfasu.edu/ita

Part of the American Material Culture Commons, Archaeological Anthropology Commons, Environmental Studies Commons, Other American Studies Commons, Other Arts and Humanities Commons, Other History of Art, Architecture, and Archaeology Commons, and the United States History Commons

Tell us how this article helped you.

This Article is brought to you for free and open access by the Center for Regional Heritage Research at SFA ScholarWorks. It has been accepted for inclusion in Index of Texas Archaeology: Open Access Gray Literature from the Lone Star State by an authorized editor of SFA ScholarWorks. For more information, please contact cdsscholarworks@sfasu.edu. 
Possible Engraved Canebrake Rattlesnake Motifs on Sherds from the Etoile Site (41NA11) in the Angelina River Basin in East Texas

\section{Creative Commons License}

\section{(c) (1) \&}

This work is licensed under a Creative Commons Attribution-NonCommercial 4.0 International License 


\title{
Possible Engraved Canebrake Rattlesnake Motifs on Sherds from the Etoile Site (41NA11) in the Angelina River Basin in East Texas
}

\author{
Timothy K. Perttula and Mark Walters
}

\section{INTRODUCTION}

Engraved canebrake rattlesnake motifs on bottles has been found in ceramic assemblages in at least 18 Middle (ca. A.D. 1200-1400) and Late Caddo (ca. A.D. 1400-1680) period sites in the Big and Little Cypress Creek, mid-Sabine, Red River, and Angelina River basins in East Texas (Gadus 2013:221; Perttula 2014; Walters 2006). The motif consists of "representational images of snakes with entwined or interlocking tails" (Gadus 2013:221).

\section{Possible Engraved Canebrake Rattlesnake Motifs on Ceramic Sherds from the Etoile Site}

At the Etoile site (41NA11) at Lake Sam Rayburn in the Angelina River basin, there are bottle sherds with possible canebrake rattlesnake elements. Both have cross-hatched zones that may represent part of the body of the snake (Figures 1a-b and 2). The third sherd is a carinated bowl rim with a curvilinear body with hatched lines and a possible rattlesnake head with dots suggesting the eyes of the snake (Figure 1c).

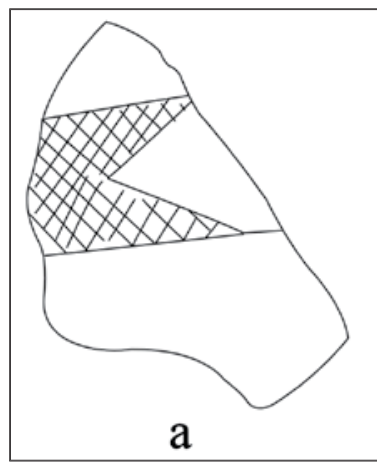

Figure 1. Drawings of engraved sherds from the Etoile site with possible engraved canebrake rattlesnake motifs.

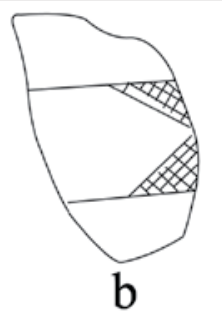

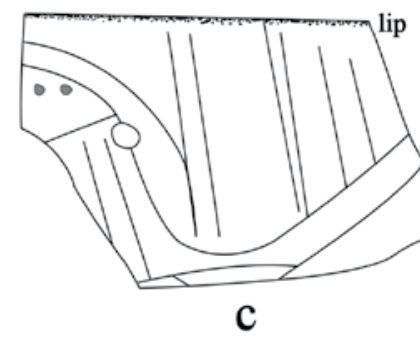

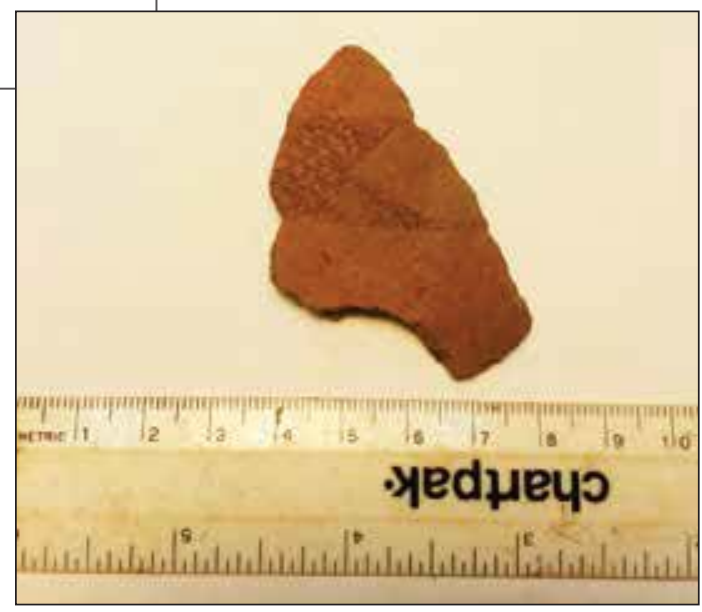

Figure 2. Photograph of the engraved rattlesnake element on bottle body sherd from the Etoile site. Photograph taken by Mark Walters. 
The Etoile site was excavated by the Texas Archeological Salvage Project in 1960 (Jelks 1965) prior to its inundation by the waters of Lake Sam Rayburn. Recovered artifacts, especially decorated sherds from both utility ware and fine ware vessels, indicates that the site was occupied during the Late Caddo period, or the late Angelina phase (see Middlebrook 1994, 1997), likely postdating ca. A.D. 1450. There is a single radiocarbon date from the Etoile site (41NA11). It is from a pit feature in the N450 profile. The conventional age is 320 \pm 70 years B.P. (Beta-97894). At 2 sigma, the calibrated age range is A.D. 1492-1649 (Perttula 1998:332).

\section{SUMMARY}

Recent reanalysis of the ceramic sherd assemblage from the Etoile site (41NA11) curated at the Texas Archeological Research Laboratory at The University of Texas at Austin has identified three sherds from bottles and a carinated bowl that may have remnants of engraved canebrake rattlesnake motifs. The Etoile site was occupied by Caddo peoples during the Late Caddo period or late Angelina phase. These findings add to the growing database of sites of Middle and Late Caddo period age sites in East Texas that have engraved representational images of rattlesnakes on fine ware vessels.

\section{ACKNOWLEDGMENTS}

Lance Trask prepared Figure 1 for this article. Thanks to the staff at the Texas Archeological Research Laboratory at The University of Texas at Austin for access to the collections from the Lake Sam Rayburn sites.

\section{REFERENCES CITED}

Gadus, E. F.

2013 Twisted Serpents and Fierce Birds: Structural Variation in Caddo Engraved Ceramic Bottle Motifs. Bulletin of the Texas Archeological Society 84:213-245

Jelks, E. B.

1965 The Archeology of McGee Bend Reservoir, Texas. Ph.D. dissertation, Department of Anthropology, The University of Texas at Austin.

Middlebrook, T. A.

1994 An Update of Archaeological Investigations at the Tyson Site. Journal of Northeast Texas Archaeology $3: 1-36$.

1997 The Caddoan Occupation of the Attoyac and Angelina River Basins in the Middle Caddoan Period. Journal of Northeast Texas Archaeology 10:36-40.

Perttula, T. K.

1998 A Compendium of Radiocarbon and Oxidizable Carbon Ratio Dates from Archaeological Sites in East Texas, with a Discussion of the Age and Dating of Select Components and Phases. Radiocarbon 39(3):305-342.

2014 The Caddo Archaeology of the Musgano Site in the Sabine River Basin of East Texas. Special Publication No. 28. Friends of Northeast Texas Archaeology, Pittsburg and Austin.

Walters, $\mathrm{M}$.

2006 The Lake Clear (41SM243) Site and Crotalus horridus atricaudatus. Caddoan Archeology Journal 15:5-41. 